\title{
The Practice of School-Based Management in Ondo State Public Secondary Schools: Implication of School Location
}

\author{
Olaseni Vivian Morenike \\ Department of Educational Management \\ Faculty of Education \\ Adekunle Ajasin University \\ Akungba Akoko, Ondo State, Nigeria \\ E-mail: olomosayev@gmail.com \\ Tel: +2348068513127
}

\section{Abstract}

The practice of School-Based Management (SBM) has been widely liked to variety of wide positives in schools and increasingly acceptable in major developed and developing nations, however, the disposition and acceptance of the SMB policy remained unclear in Ondo State, Nigeria. In Nigeria, there is paucity of literature addressing the role of school location in the practice of SBM policy. This study, therefore examined the practicality of SBM in public secondary schools in Ondo State and the implication of school location. Descriptive survey design was adopted by the study. Key players from sixty (60) public secondary schools in Ondo State participated in the current study using purposive sampling techniques. In determine the efficiencies and effectiveness of School-Based Management Committees, participant were opened to Effective School-Based Management Index (E-SBM-INDEX). The instrument reported a strong overall Cronbach alpha of 0.97 , while the subscales factors entails, power decentralization $(\alpha=.92)$; facilities obligation $(\alpha=.73)$; monitoring and evaluation $(\alpha=.65)$; recruitment and retrenchment $(\alpha$ $=.85)$; and financial obligation $(\alpha=.7 \mathrm{I})$. Information on socio-demographic factors and geographical location of schools were also obtained from the participants. Descriptive analysis and T-Test of independent sample were used to analyze data and accepted at $\mathrm{P} \leq 0.05$. Respondents' mean age was $49.5 \pm$ II .5 years. It was revealed that $35 \%$ of the public schools engaged practice effective SBM in Ondo State, while 65\% of public schools engaged were practicing ineffective SBM. Furthermore, It was revealed that there was significant difference in the practice of SBM in rural and urban public secondary schools in Ondo State $(\mathrm{T}(58)=26.60 ; \mathrm{P}<0.0 \mathrm{I})$, such that, public secondary schools located in the rural area $(\bar{X}=75.20, \mathrm{SD}=\mathrm{I} .80)$ practice effective SBM's policy than counterparts located in the urban area $(\overline{\boldsymbol{X}}=34.97, \mathrm{SD}=02.67)$. Majorly the practice of SBM in public secondary school remained ineffective in Ondo State. The practice of SBM in rural and urban public secondary schools in Ondo State is significantly different. Public secondary schools located in the rural area of Ondo State practice effectively SBM's policy than public secondary schools located in the urban area of Ondo State. It is recommended that the government should be pro-active in creating an enabling environment in terms of policy upon which SBM can be practice effectively and efficiently.

Keywords: Decentralization, School Administration, School-Based Management, School Location, Ondo State. (5)

\section{Introduction}

School-Based Management (SBM) is the decentralization of authorities and power from solely the government to governmentbased agents, community-based agents, and school-based agents. The key players or agents in the SBM model are often time 
addressed as the School-Based Management Committees (SMBC). The SBMCs entails that the government representatives of government or agents often regarded as education officers representatives of the Ministry of Education, and Teaching Service Commission (TESCOM); school agents of SBMCs entails principals, head of subject teachers, current and old student representatives, representatives of PTA, representatives of National Union of Teachers; and community agents of SBMCs which entails local traditional leaders, religious leaders, representatives of residents associations, representatives of youth, communitybased philanthropists and councilors.

SBM has been identified in the past to foster school development and ensures that schools provide quality, social and economic benefits that best reflect the core values and priorities of the local communities (Lewis, 2006). SBM allows schools more autonomy in the use of their human, material and financial resources. Member nations of the Education reforms in Organisation for Economic Co-operation and Development (OECD) often share essential common characteristics, including greater responsiveness to local needs, increased school autonomy, and objective of improving students' academic performances (OECD, 2004; Olaseni \& Ibukun, 2016).

The World Bank education portfolio for 2000 to 2006 fiscal years out rightly supported the active practice of SBM, such that 23 percent of the Bank's total education finance was allocated (Heylighen \& Joslyn, 2008). For over a decade, the trend of SMB has become so popular such that numerous countries with diverse cultures (Hong Kong, the United Kingdom, El Salvador, Guatemala, Mexico, New Zealand, Thailand, United States, Nicaragua, Spain, the Netherlands, Israel others) have instituted SBM program in their respective countries (Gray, 2004; Taylor \& Bogotch, 2004; Petty \& Green, 2007; Caldwell, 2005).

The place of school location in the implementation of SBM remained unclear. One of the objectives of SBM policy has been to bridge the gap between the quality of education that is obtainable in rural and urban communities. However, community agent of SBMCs has been reported very active in school management than other arms of SBMCs in the rural communities and better when compared to urban communities. It is widely assumed that parental participation may work effectively in the rural districts than urban communities because of limited educational resources, both human and financial. Schools in rural or remote areas are often facing more severe situations like a small-size classroom and lack experienced teachers than the urban located schools.

\section{Theoretical and Conceptual Framework: System Management Theory (SMT)}

In an attempt to situate this research work within theoretical frameworks, and understand the concept School Based Management, this study was guided using SMT theory. SMT constituted the study theoretical framework because it considers significantly and respect every formation members of any system and describe the way each component functions together and impacted one another to achieve a wholesome vision and mission. This theory looks at chain reaction in organization and how the reactions impact other parts of a system. According to Ibukun (2008) a system is a set of identified elements which interact among themselves and with its environment to perform a specific function. School as a system enables the stakeholders to view the school as a social organization that has many components that inter-relate and inter-depend on one another for the purpose of achieving the educational goals. Mc Qurrey (2012) sees a system as a whole made up of parts. Each part can affect the way other part works and the way all part works together will determine how well the system works. That is, the school should not be separated from the community. The input of the commitment-holders in education could be better harnessed through the School Based Management. Find below the conceptual framework of the 


\section{Conceptual Framework of SBM}

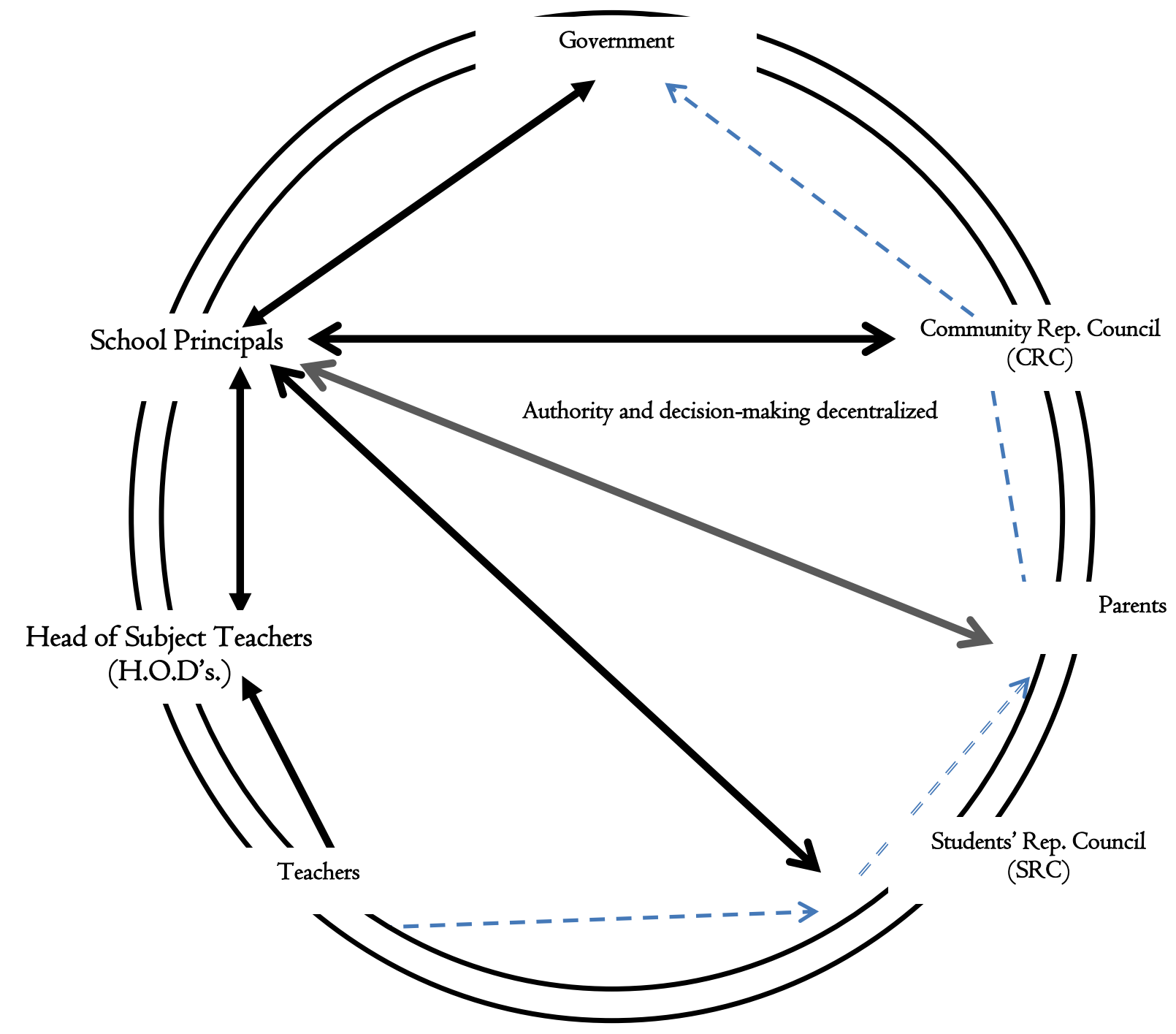

Source: Olaseni (2016)

The diagram above explains how school based management committees interact together to pass information and how feedback are delivered. The school principal receives information directly from the government and as well gives the feedback agreed on by the SBMC to the government. He as well passes information to both the head teachers, students representatives, parents and the community of the school while the head teachers also passes the information to the subjects teachers in which thereafter, these whole committees give their feedback to the principal who then take the information to the government. The committee members also go to the principal to obtain or to deliver information.

\section{Literature Review}

The model of SBM has been well popular and considered as an adopted improving tool in providing excellent quality education to students and improving school management, transparency, accountability, and responsibilities. Most countries whose students perform well in international students' achievement tests were reported to give local authorities and schools substantial autonomy to decide the content of their curriculum and management of their resources. SMB has been very laudable in improving the significantly academic performance of students as established by numerous scholars (e.g., Borman et al. 2003), increases students' interest and participation in science subjects (e.g., Gropello \& Marshall, 2005); efficient school performance (McKinsey \& Company, 2010) among others.

The study conducted by Sun (2007) revealed that rapid changes in schools that have adopted the practice of SBM. Increasing number of developing and developed nations are adopting the SBM system as interventions for enhancing quality 
education. SBM empowers school agents (principals, teachers, students \& parents) by strengthening their motivation and increases their sense of ownership of the school. Chaudhury \& Parajuli, (2010) revealed that SBM engaged and increased parental involvement in the school other than the Parent Teacher Association, whereby parents without wards are not permitted to participate in the school's affairs, in regardless of how much interest or capacity they have to influence the development of the school in terms of facilities, supervision and the likes

The study of Shatkin and Gershberg (2007) conducted using a case study method to study the effects parents and community members' (agent of SBMC) participation in school leadership in Texas, Chicago, Hawaii, and Kentucky. It was concluded particularly that community agents (parents and community) participation in educational leadership enhances governance and accountability which impacted students' academic outcome. A similar finding was reported in the study of Joseph (20II) who revealed that family and community environment determine academic success. A qualitative study conducted by Ayeni (2012) examining the role of school agents (principals \& Teachers) in enhancing quality assurance in the secondary school in Ondo State, Nigeria concluded that school agents play a significant role in improving quality of secondary school education in Ondo State, Nigeria.

The study of Reimers and Cardenas (2007) purposed to examine educational governance at local level, vis-a-vis the benefits of school-based management. It was revealed that schools located in the urban region of Mexico practiced School-Based Management significantly much better (29\%) than schools located in the rural part of Mexico. It was also revealed that indigent students benefitted better from the SBM policy than students with average or good economic status. The study of Ai Shoraku (2009) purposed to examine educational movement toward School-based Management in East Asia revealed that over $90 \%$ of the rural community agents of SBMCs interviewed during data gathering mentioned participating in activities to the school activities, particularly financial commitment than those in the urban communities. The percentage of financial commitment was quite large, compared to the other responsibilities such as; attending an opening or closing ceremony, attending a meeting at school or engaged in policy and decision making. Some of the money contributed was for new buildings, preparation of opening and/or other ritual school activities, and school lunches.

There is a paucity of literature addressing the efficiencies of SBM policy in Ondo State, Nigeria. Though SBM remained focus on ensuring quality and adequate education in rural and urban communities but the practice in the rural and urban communities in Ondo State remained unclear and undebated. Hence, this study examines the practicality of SBM in secondary schools in Ondo State and the implication of school location.

\section{Research Objectives}

- To examine the effectiveness of SBM practice in the public secondary schools in Ondo State, Nigeria

- To explore the non-significant difference in the practice of SBM between schools in rural and urban communities of Ondo State.

\section{Hypothesis}

HOI There is no significant difference in the practice of SBM between schools in rural and urban communities of Ondo State.

\section{Methodology}

Design/Sampling: Descriptive survey design was used with survey methods. The study settings were selected from the three senatorial districts of Ondo State. Thus a purposive random sampling method was adopted to select and engage principals from twenty (20) public secondary schools in each district (ten urban and ten rural) of the state into the research.

Instrument: The data for the study was collected through the Effective School-Based Management Index (E-SBM-INDEX). ESBM-INDEX is a-27 item inventory that was developed by Olaseni (2016) to determine the efficiencies and effectiveness of constituted School-Based Management Committees. The subscales factors entails, power decentralization $(\alpha=.92)$; facilities obligation $(\alpha=.73)$; monitoring and evaluation $(\alpha=.65)$; recruitment and retrenchment $(\alpha=.85)$; and financial obligation $(\alpha$ $=.7 \mathrm{I})$. The E-SBM-INDEX has a significant Cronbach alpha of 0.97, indicating an acceptable level of reliability. The validity of E-SBM-INDEX has established through the construct (discriminant and convergent) validity.

\section{Results}

\section{Research Objective I}

The research objective one which was set to examine the effectiveness of SBM practice in the public secondary schools in Ondo State, Nigeria is presented table I using descriptive analysis.

Table I: Showing the norm and percentage of effective SBM adoption in the Urban and Rural Public Secondary Schools of Ondo State.

\begin{tabular}{cccc}
\hline Class of Interval & Frequencies $\mathrm{F}(\mathrm{n})$ & $\mathrm{F}(\%)$ & SBM \\
\hline $90-\mathrm{I} 20$ & $2 \mathrm{I}$ & $35 \%$ & Effective Practice \\
\hline $6 \mathrm{I}-90$ & & & Ineffective Practice \\
\hline $3 \mathrm{I}-60$ & 39 & $65 \%$ & \\
\hline $00-30$ & & &
\end{tabular}

Source: Field Survey, 2018 
Table I presents the numbers of schools sampled to participate in this study, 60 schools were sampled and the total score for SBM Effectiveness is I20 in which the researcher considered those who scored above the norm ( $\geq 61 \%)$ to be effective in the practice of SBM and schools below the norm $(<60)$ below to be Less-effective in the practice of SBM. This implies that 35\% (2I out of the 60 sampled) schools practice effective SBM in Ondo State while $65 \%$ (that is 39 out of the total 60 schools used in the research) do not practice an effective SBM.

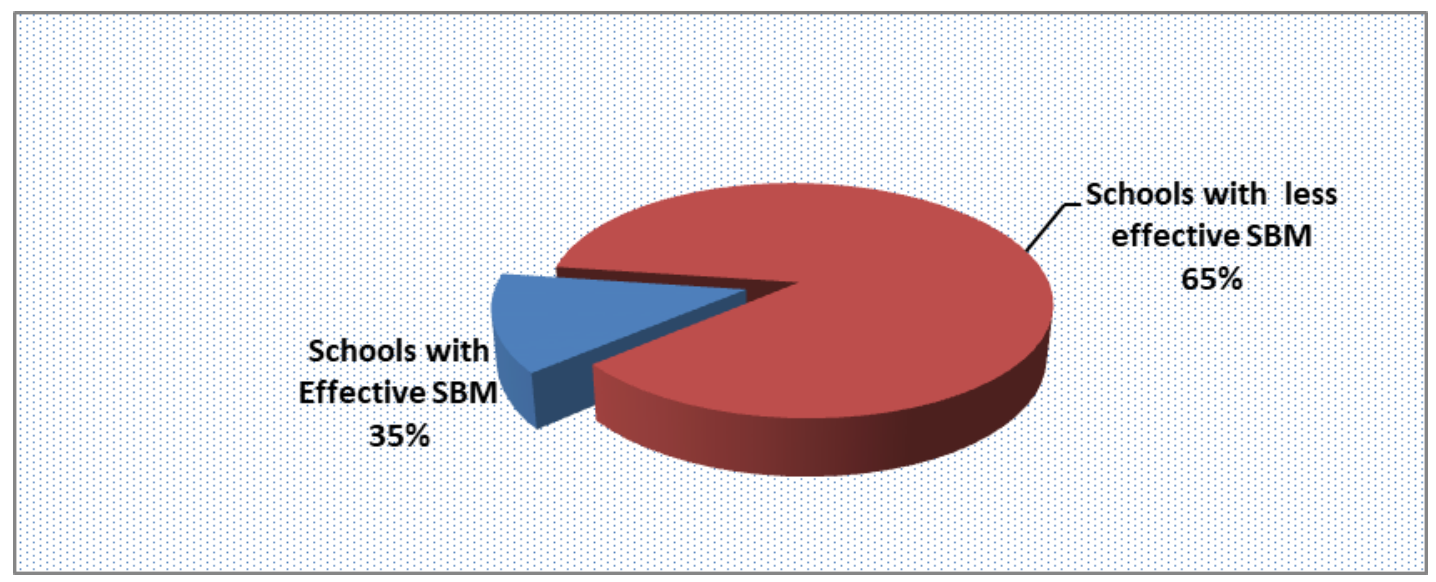

Figure I: Pie Chart Showing the Level of Effective SBM adoption in Urban and Rural Public Secondary Schools in Ondo State Source: Derived from Table I

\section{Research Objective 2}

The research objective two which was set to explore no significant difference in the practice of SBM between schools in rural and urban communities of Ondo State was presented table 2 using T-Test of independent sample.

Table 2 Showing the significant difference in the SBM practice between schools in rural and urban communities of Ondo State

\begin{tabular}{cccccccc}
\hline & Location & $\mathrm{N}$ & $\bar{X}$ & $\mathrm{SD}$ & $\mathrm{df}$ & $\mathrm{T}$ & $\mathrm{P}$ \\
\hline & Rural & $\mathrm{I} 8$ & 75.20 & 01.80 & & & \\
\hline SBM & & & & & 58 & 26.60 & $<.01$ \\
\hline & Urban & 42 & 34.97 & 02.67 & & & \\
\hline
\end{tabular}

Table 2 presented the result showing the significant difference in the practice of SBM in the public secondary schools located in the rural and urban communities of Ondo State. It was revealed that there was significant difference in the practice of SBM in rural and urban public secondary schools in Ondo State $(\mathrm{T}(58)=26.60 ; \mathrm{P}<0.0 \mathrm{I})$. It was further revealed that public secondary schools located in the rural area $(\bar{X}=75.20, \mathrm{SD}=1.80)$ of Ondo State practice effectively SBM's policy than public secondary schools located in the urban area $(\bar{X}=34.97, \mathrm{SD}=02.67)$ of Ondo State. The outcome negates the stated objective two which proposed that no significant difference in the practice of SBM between schools in rural and urban communities of Ondo State. The null hypothesis was therefore rejected, while the alternate hypothesis is therefore accepted.

8. Discussion and Conclusion

From the findings, aside from low acceptance of School-Based Management in Ondo State, it was revealed that there is low acceptance of SBM in Ondo State public Secondary Schools. The level of adoption and acceptance of SBM in Ondo State Secondary Schools for the effective schools is $35 \%$ while for the less effective schools is $65 \%$. This corroborates the findings by the Federal Ministry of Education (20II) that a significant proportion of $60 \%$ of schools is without functional SBMC. This situation could be partly attributed to problems such as inadequate sensitization and advocacy for the government, school leadership and communities to understand the enormous benefits to be derived from their genuine participation in school governance, particularly in raising teaching and learning standards, and quality of outputs in schools.

Furthermore, it was revealed that most schools located in the rural area of Ondo state practice more effectively the policy of SBM when compared to public secondary schools situated in the urban region of Ondo State. However, the findings revealed that the difference observed in the practice of SBM in the schools located in rural and urban communities was very significant. The result implied that the exposed the location of the school, the less effective the practice of school-based management, or the less exposed the position of the school, the effective the practice of school-based management. The possible reason for the 
outcome could be that occupants in the rural area have more time to be the focus and devoted to the activities of education and other things while those in the urban seems to be too busy to participate in the school activities.

Moreso, public secondary schools in the rural communities of Ondo State attract much or better commitment to SBMCs than public secondary schools in the urban communities because schools in the rural areas have limited educational resources, such as; ill-equipped laboratory, lack of books or updated books in the library, lack experienced teachers, among others. The outcome was in agreement with the findings of Reimers and Cardenas (2007) and Ai Shoraku (2009) that reported better practice and benefits of SBM policy in the rural region than the urban region.

\section{Recommendation}

- This study discovered low effectiveness in the practice of SBM in Nigeria. Government to put in place the right school administrative management or policy which will improve the acceptance of SBM in Ondo State public secondary schools by increasing parental and community involvement in school administration, whereby, parents and the community members monitor/supervise the acquisition and utilization of teaching and learning materials in the school and staffs are motivated to be more committed to their duties.

- Effective delivery of SBM should be ensured by the authorities concerned in the rural and more importantly, the urban communities. The education policymakers should also make decision making more open to the school community members who are the immediate beneficiaries of the school rather than generalizing a rule which might not apply to all communities.

- The results of the research could assist the policy makers in education to formulate a result-oriented policy that will incorporate the concept of school-based management in the running of the school system. This will no doubt enhance parents and community participation in the system and improve quality service delivery and better learning outcome in Nigerian secondary schools.

\section{References}

Ai Shoraku (2009). Strategic Change Management on Education: The future is ours to build. India: Pune press publisher.

Alimi, O.S. (2012), Community based school management: A Seminar paper on Effective management of secondary schools in Ondo State. Ikare Amure Printing Press.

Ayeni, A. J. (2010). Teachers' instructional task performance and principals' supervisory roles as correlates of quality assurance in secondary schools in Ondo State. (Unpublished doctoral dissertation)Obafemi Awolowo University, Ile-Ife, Nigeria.

Caldwell, B.J. (2005A). School Based Management Paris: International Academy of Education and International Institute for Educational Planning.

Chaudhury, F \& Parajuli, N. (2010). Educational Development; The future of school effectiveness and improvement in school,9(2), pp I25-I34.

Gray, J. (2004). School effectiveness and the 'other outcomes' of secondary schooling: A Reassessment of curriculum delivery. Improving schools, 7(2), I85-I98.

Lewis, B. (2006). Home influence on school learning: Direct and indirect effect of parental involvement on high school grades. Journal of educational research, 80(5), 330-336.

Mc'Querry, A. (2012). Managing the education system: a review of the schools' general Operational system in Britain. Journal of Educational Leadership Style. 4(2) 19-25.

Reimers and Cardenas (2007). Educational restoration: Leading the self-managing school. London: Falmer Press.

Shatkin, H. \& Gershberg (2007). Developing a relationship between the school and the community. School Improvement and accountability 8(2), I3-22.

Sullaiman.A. (2009).Education sector support programme: Memorandum on need to hold on and strengthen the education system in Nigeria. Ibadan Sabork Publisher.

Sun, H. (2007); Petty, N.W \& Green. T. (2007), School Effectiveness and Learners Outcome I6(3),249-279.

Ibukun.W.O. (2013). The Role of School Based Management Committees in the administration of secondary schools in Nigeria. A Journal of Global Education Services, 2(I).

Ibukun.W. O. (2008). Principles of educational management. Akure: Pub:Stebak Books.

\section{Copyrights}

Copyright for this article is retained by the author(s), with first publication rights granted to the journal. This is an open-access article distributed under the terms and conditions of the Creative Commons Attribution license (http://creativecommons.org/licenses/by/4.0/). 